\title{
RESEARCH AND CHANGES IN BERRIES USING TECHNOLOGY OF FREEZING DURING STORAGE
}

\author{
Serhii Kiurchev ${ }^{1}$, Valentuna Verkholantseva ${ }^{1}$, Oksana Yeremenko ${ }^{1}$, Faten Al-Nadzhar ${ }^{2}$ \\ ${ }^{1}$ Tavria State Agrotechnological University, Ukraine; ${ }^{2}$ Abu Dhabi University, United Arab Emirates \\ valentyna.verkholantseva@tsatu.edu.ua,dakgps@pdatu.edu.ua
}

\begin{abstract}
There is an acute problem of providing the population with food products that would not only fully satisfy the energy needs of the human body, but also provide the physiological needs of the human body in vitamins, minerals and other biologically active substances. An important role in providing the population with micronutrients can be played by berries, which are a natural concentrate of biologically active substances. Lowtemperature technologies for preserving berries can significantly increase the production of this high-value raw material, due to which it is possible to significantly improve the nutrition structure, thereby improving the quality of life of the population. This explains the rapid growth in the last decade of the production of frozen fruits and berries and, as a result, the intensive development of food low-temperature technologies. The experimental data during the studies were obtained. The temperature regimes for storing berries with the preservation of quality indicators are given. Low-temperature processing is sometimes the only feasible method of practically year-round storage and transportation for unlimited distances, so freezing in growing areas is a promising method to solve the problem of delivering berries at any distance, to eliminate the seasonality of its consumption, which ensures the stability of nutritional value. Fluidization freezing, similar to drying in the suspended state, is characterized by very intense heat exchange. Freezing berries is a special method of preserving them retaining the nutritional value and taste of the product. The high speed of the process and the formation of the smallest ice crystals prevent the loss of moisture in berries.
\end{abstract}

Keywords: freezing, temperature, storage, crystal, berries.

\section{Introduction}

From harvest to sale, the berries undergo various changes. During the growth berries accumulate useful substances, and during storage they lose. Therefore, the main task when storing berries is to create conditions, under which nutrient loss would be minimal and the product quality would remain the same as after harvest. At high temperature there is an accelerated metabolism, loss of moisture, vitamins, organic substances, therefore, the fruits ripen and spoil faster. Therefore, it is extremely important to cool the products intended for bookmarking as shortly as possible (short-term (several days to 1-2 months)) or for long-term (2 to 10 months) storage as soon as possible.

Berries are characterized by low resistance to pathogens and rapid aging of tissues, therefore, the determining factor in the establishment of the pre-cooling mode is speed.

Cooling speed is necessary to slow down the vital processes occurring in berries, to prevent the development of microorganisms in the external environment and to reduce moisture loss from the products. Also, an important element of the pre-cooling technology is the allowable length of time between product collection and the start of its cooling [1;2].

For most berries, cooling must be carried out as soon as possible after harvesting. Cooling immediately after collection also helps maintain high levels of Vitamin C, tannins and colorants. This leads to a longer preservation of the natural taste qualities of the fruit, good marketable appearance and provides greater yield.

Pre-cooling is especially effective for fragile and delicate berries destined for long-distance transport, as well as at high outdoor temperatures in the area of fruit sprouting with which their initial temperature is associated. The latter is determined by the timing of the harvest [2-5].

\section{Materials and methods}

Freezing freezer - the freezing process takes place in a stream of cold air in a suspended state. Ideal for freezing foods with a delicate texture - berries, fruits, sliced vegetables, mushrooms, small fish and shrimp. Fluidizing freezers allow to get frozen products without damaging the highest quality $[3 ; 4]$. 
In the course of experimental studies, raspberries and strawberries were selected. For the experiments, raspberries of two varieties were selected: Brusvyana, Sugana gold and strawberries of two varieties: Albion, San Andreas.

It should be noted that in the course of the experiment the size of berries was determined and their change in chemical composition, and the content of sugars, organic acids, the content of vitamin C.

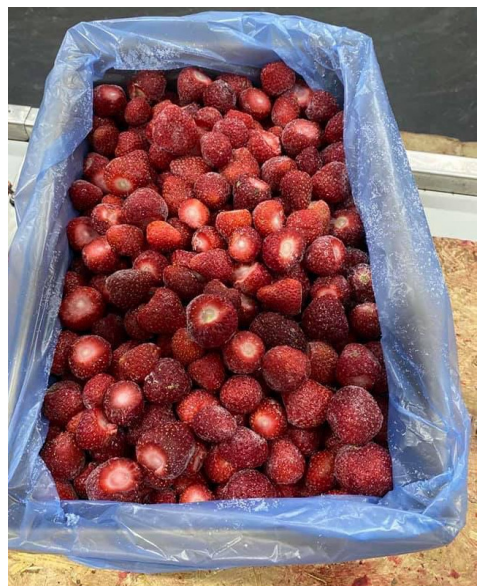

Fig. 1. Experimental sample (strawberry)

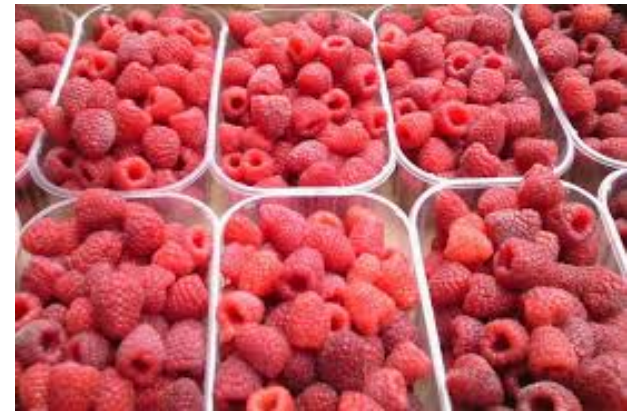

Fig. 2. Experimental sample (raspberry)

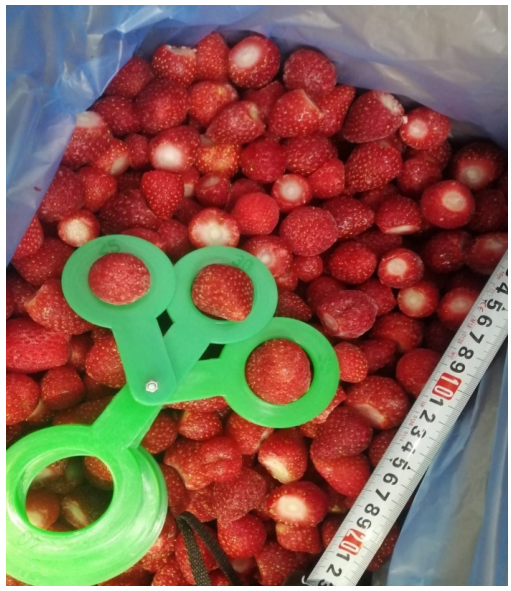

Fig. 3. Determination of strawberry size during experimental studies

\section{Results and discussion}

This problem is solved by the fact that in a vibrating freezer containing a mesh conveyor connected to the evaporator of the refrigerating unit through the channels of distribution of lowtemperature air, fan, tension device, supports of the vehicle, supporting rollers, window loading freeze, according to the proposed utility model, installed unbalance vibrator, support rollers mounted on movable axes, support made spring, tension device, equipped with a spring and a damper $[1 ; 6-10]$.

The use of vibration freezing device of the proposed design, through the installation of an unbalance vibrator, supporting rollers on the moving axes, the execution of spring supports and equipment tensioning device with a spring and a damper, reduces energy consumption, improves the vertical movement of the product, which is frozen and eliminated in general.

The technical essence is explained by the drawing, which shows a schematic diagram of the device. Vibrating freezer contains a mesh conveyor 1 connected to the evaporator of the refrigeration unit through the air ducts of low-temperature air distribution, fan (not shown), rollers 2, 3, moving axes 4,5 , unbalance vibrator 6 , tensioning device 78 , loading window 9 , unloading window 10 , spring 11, damper 12, product 13, which is frozen (Fig. 4). 


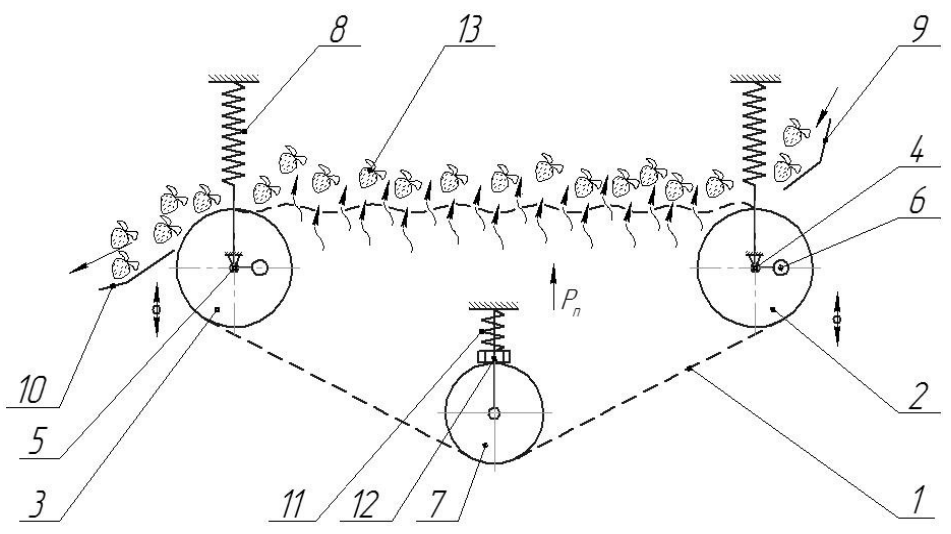

Fig. 4. Schematic representation of a vibration freezer: 1 - conveyor; 2, 3- rollers; 4, 5 - axes;

6 - unbalance vibrator; 7, 8 - tensioning device; 9 - loading window; 10 - unloading window;

11 - spring; 12 - damper; 13 - product

In the freezing shop a vibrating freezer is mounted: a mesh conveyor 1 connected to the evaporator (not shown) of the refrigerating unit through the channels (not shown) of low-temperature air distribution, installing a fan (not shown), supporting rollers 2,3 , rollers 4,5 , unbalance vibrator 6 , tension device 7 , spring supports 8 , loading window 9 , unloading window 10 , spring 11 , damper 12 . The product 13, which is frozen through the loading window 9 is fed to the mesh transporting and means 1 , where its horizontal and vertical movement begins and a fluidized bed is formed under the action of the unbalance vibrator 6 , the rollers 2,3 , mounted on the moving axes 4,5 and the spring supports 8 , the tensioning device 7 is equipped with a spring 11 , damping 12 stabilizes 1 .

At the same time, included a fan (not shown), which through the evaporator (not shown) of the refrigerating unit with channels (not shown) of air distribution, supplies cool low temperature air under the mesh conveyor. The stream of air passes through the frozen product layer 13. Freezing of the product 13 occurs in the fluidized bed formed by the horizontal and vertical movement of the mesh conveyor 1 , which delicately tosses it, preventing injury or damage, as in the prototype. The cycle is then repeated.

The process of freezing strawberries and raspberries was carried out with the help of the developed vibration freezing device.

During the experiment, all analyses were obtained using laboratory tests during the storage period, that is, they were performed in a certified laboratory.

A range favorable for cooling and freezing was selected. The data are recorded in the table (Table1) and graphs are constructed (Fig. 5).

Table 1

Changes in temperature during the rapid freezing process

\begin{tabular}{|c|c|c|c|c|}
\hline Variety of berries & $\begin{array}{c}\text { Raspberry } \\
(\text { Brusvyana) }\end{array}$ & $\begin{array}{c}\text { Raspberry } \\
(\text { Sugana gold) }\end{array}$ & $\begin{array}{c}\text { Strawberry } \\
(\text { Albion })\end{array}$ & $\begin{array}{c}\text { Strawberry } \\
(\text { San Andreas })\end{array}$ \\
\hline Temperature, $\boldsymbol{t}^{\mathbf{}} \mathbf{C}$ & time, $(\boldsymbol{\tau}, \mathbf{m i n})$ & time, $(\boldsymbol{\tau}, \mathbf{m i n})$ & time, $(\boldsymbol{\tau}, \mathbf{m i n})$ & time, $(\boldsymbol{\tau}$, min) \\
\hline 5 & 3 & 4 & 6 & 8 \\
\hline 2 & 6 & 6 & 8 & 10 \\
\hline 0 & 8 & 8 & 10 & 12 \\
\hline-2 & 14 & 15 & 16 & 18 \\
\hline-5 & 16 & 17 & 20 & 24 \\
\hline-10 & 18 & 18 & 22 & 25 \\
\hline-15 & 19 & 19 & 25 & 27 \\
\hline-20 & 20 & 20 & 28 & 28 \\
\hline-25 & 21 & 21 & 30 & 30 \\
\hline
\end{tabular}




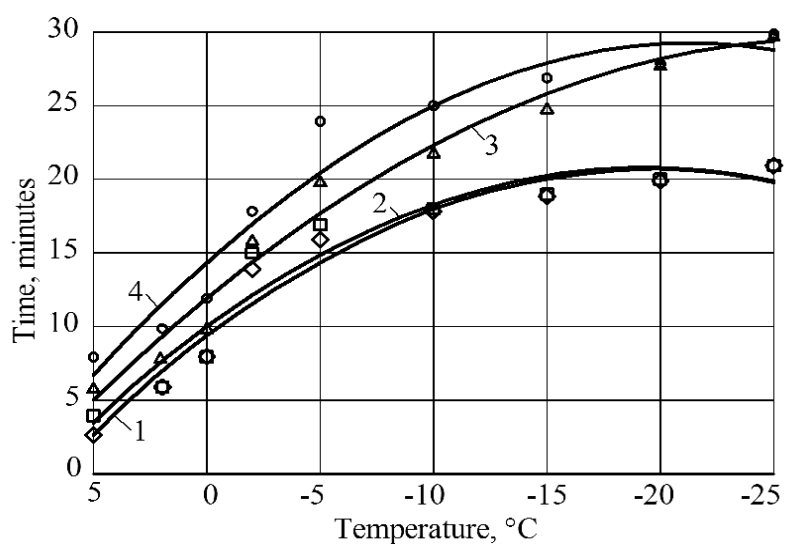

Fig. 5. Dependence of temperature change during the cooling stage before freezing of strawberries and raspberries: 1 - raspberry (Brusvyana); 2 - raspberry (Sugana gold); 3 - strawberry(Albion); 4 - strawberry(San Andreas)

From the graphic part it is possible to observe what happens to the berry during storage, that is, changes are related to the composition of strawberries and raspberries (Table2-4). In some indicators, the composition changed for the better, and for some it deteriorated (Fig. 6-8).

Table 2

Sugar content during storage, $\%$

\begin{tabular}{|c|c|c|c|c|}
\hline $\begin{array}{c}\text { Storage term, } \tau, \\
\text { month }\end{array}$ & $\begin{array}{c}\text { Raspberry } \\
\text { (Brusvyana) }\end{array}$ & $\begin{array}{c}\text { Raspberry } \\
\text { (Sugana gold) }\end{array}$ & $\begin{array}{c}\text { Strawberry } \\
\text { (Albion) }\end{array}$ & $\begin{array}{c}\text { Strawberry } \\
\text { (San Andreas) }\end{array}$ \\
\hline 0 & 5.7 & 7 & 5.7 & 6.9 \\
\hline 3 & 3.9 & 6.5 & 5.5 & 6.6 \\
\hline 6 & 3.5 & 5.5 & 5.1 & 6.1 \\
\hline
\end{tabular}

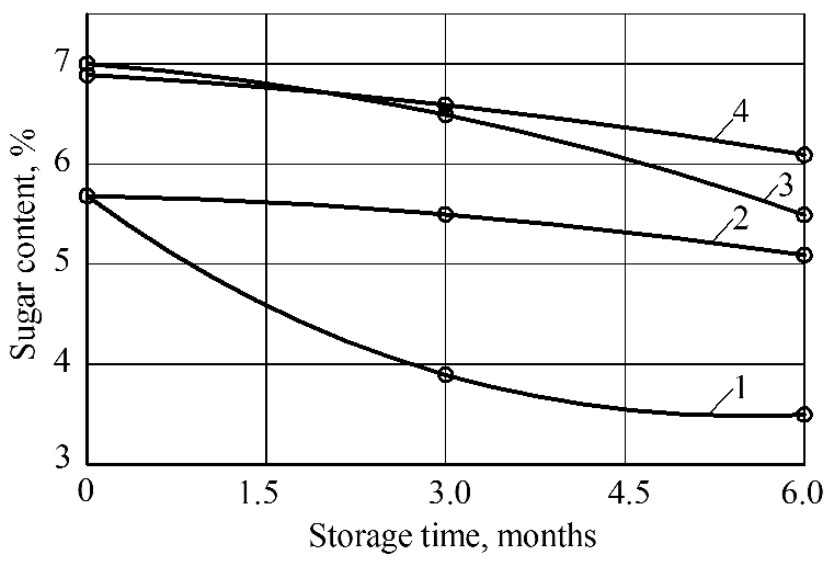

Fig. 6. Dependence of sugar content during storage after freezing of berries: 1 - raspberry (Brusvyana); 2 - strawberry (Albion); 3 - raspberry (Sugana gold); 4 - strawberry(San Andreas)

Organic acids content during storage, $\%$

\begin{tabular}{|c|c|c|c|c|}
\hline $\begin{array}{c}\text { Storage term, } \boldsymbol{\tau}, \\
\text { month }\end{array}$ & $\begin{array}{c}\text { Raspberry } \\
\text { (Brusvyana) }\end{array}$ & $\begin{array}{c}\text { Raspberry } \\
\text { (Sugana gold) }\end{array}$ & $\begin{array}{c}\text { Strawberry } \\
\text { (Albion) }\end{array}$ & $\begin{array}{c}\text { Strawberry } \\
\text { (San Andreas) }\end{array}$ \\
\hline 0 & 1.77 & 1.9 & 1.6 & 1.5 \\
\hline 3 & 2,3 & 2.34 & 2.05 & 1.6 \\
\hline 6 & 2.1 & 2.2 & 1.8 & 1.4 \\
\hline
\end{tabular}




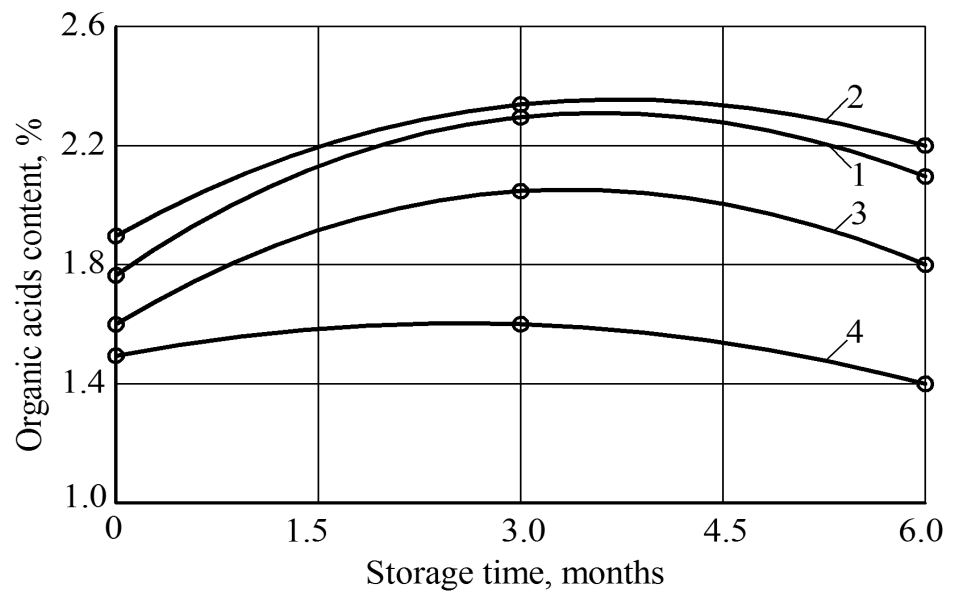

Fig. 7. Dependence of organic acids content during storage after freezing of berries: 1 - raspberry (Brusvyana); 2 - raspberry (Sugana gold); 2 - strawberry (Albion); 4 - strawberry (San Andreas)

Content of Vitamin C during storage, \%

Table 4

\begin{tabular}{|c|c|c|c|c|}
\hline $\begin{array}{c}\text { Storage term, } \tau, \\
\text { month }\end{array}$ & $\begin{array}{c}\text { Raspberry } \\
\text { (Brusvyana) }\end{array}$ & $\begin{array}{c}\text { Raspberry } \\
\text { (Sugana gold) }\end{array}$ & $\begin{array}{c}\text { Strawberry } \\
\text { (Albion) }\end{array}$ & $\begin{array}{c}\text { Strawberry } \\
\text { (San Andreas) }\end{array}$ \\
\hline 0 & 25 & 25.8 & 55 & 50 \\
\hline 3 & 23 & 24.2 & 53 & 47 \\
\hline 6 & 21 & 21.5 & 52 & 44 \\
\hline
\end{tabular}

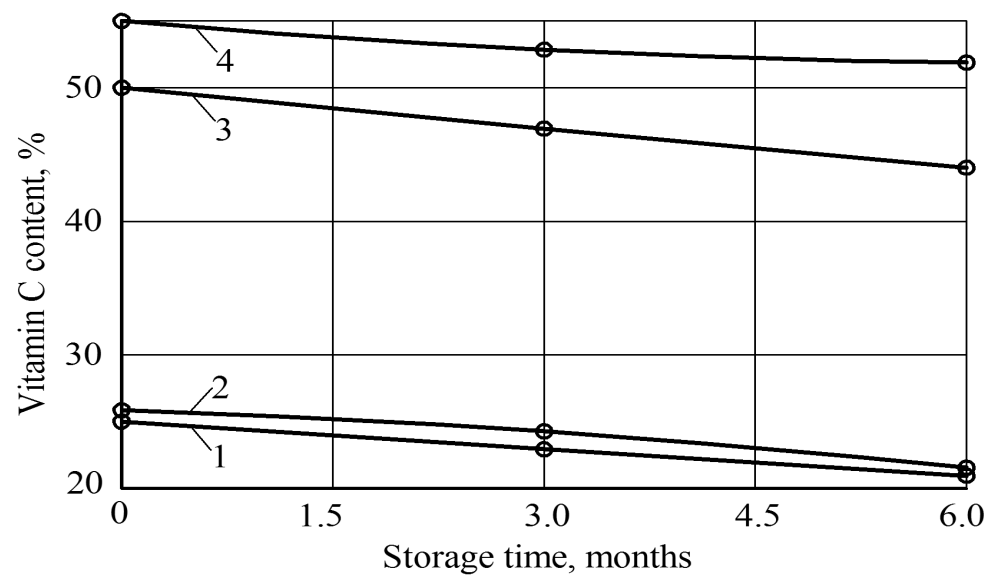

Fig. 8. Dependence of content of Vitamin $\mathbf{C}$ during storage after freezing of berries: 1 - raspberry (Brusvyana); 2 - raspberry (Sugana gold); 3 - strawberry (San Andreas); 4 - strawberry (Albion)

Concerning the graphic part, we can conclude that the process of freezing strawberries takes longer than that of raspberries with the same temperature range. Consider each indicator separately. There is a downward trend in sugar. We would like to note that with raspberries it decreases faster compared to strawberries. With organic acid, on the contrary, in raspberries it increases in both varieties, and in strawberries in one it increases and in the other decreases. Vitamin $\mathrm{C}$ indicates that they have twice the difference at the beginning, and in the process of storage in raspberries and strawberries reduced.

\section{Conclusions}

The products are conveyed by the conveyor to the freezer where the freezing cycle takes place. Due to the speed of the air flow, the particles of the products that will be subjected to freezing are not deformed. The product itself forms a protective film that prevents the juice from leaving the berries or 
vegetables. Thus, freezing is practically irreplaceable in the field of food storage. The freezing process itself will depend on the type of product.

The nutritional and biological value of fruits and berries is conditioned by the high content of vitamins, carbohydrates, pectigines, which are necessary for humans, wines and minerals. Fresh-look implementation limits the cost and scope of their consumption. Cold water canning preserves up to 40$60 \%$ of biologically active components, while with Their pasteurization and sterilization methods 10$15 \%$ of the fresh fruit content. High-speed fast-growing fruit and berries will give the opportunity to expand the variety by increasing the quality and the production of products not only by mass, but also by dietary purpose.

\section{References}

[1] Mazurenko, A.G. Freezing of foodstuffs in blocks / A.G. Mazurenko, V.G. Fedorov. -M .: Agropromizdat, 1988.-205 p.

[2] Skorikova, Yu.G. Storage of vegetables and fruits for processing / Yu. G. Skorikova.-M., 1982. $200 \mathrm{p}$.

[3] Priss O., Yevlash V., Zhukova V. ,Kiurchev S., Verkholantseva V Effect of abiotic factors on the respiration intensity of fruit vegetables during storage //Eastern European Journal of Enterprise Technologies.-2017.-Vol. 6/11(90).- pp. 27-34.

[4] Tokar A., Matenchuk L., Kharchenko Z., Haidai I., Zahorko N., Tarasenko V., Verkholantseva V., Palianychka N., Povorozniuk I., Kravchenko L. Combination of vegetable-fruit formulation composition for obtaining high quality products, Eastern-European Journal of Enterprise Technologies. - Vol. 4/11 ( 94 ) 2018.

[5] Yalpachik V.F., Zagorko N.P., Kiurchev S.V., Tarasenko V.G., Kiurcheva L.M., Budenko S.F., Grigorenko O.V., Struchaev M.I., Verkholantseva V.O. Optimization of technology of freezing of fruit and vegetable products: Monograph, Melitopol: Publishing House of Melitopol City Printing House, 2018. - 198.

[6] Samoichuk K.O., Sklar O.G., Kiurchev S.V., Budenko S.F., Verkholantseva V.O., Palyanichka N.O., Tarasenko V.G., Tsib V.G., Zagorko N.P., Kurcheva L.M., Gaprindashvili N.A. Equipment for storing fruits and vegetables and meat and dairy products. Tutorial. Melitopol: Publishing House of Melitopol City Printing House, 2019. - 186 p.

[7] Yalpachik V.F., Zagorko N.P., Palyanichka N.O, Budenko S.F., Samoichuk K.O., Kiurchev S.V, Verkholantseva V.O., Oleksienko V.O., Cib V.G. Yalpachik VF Technological Equipment for Processing Plant Production: Laboratory Workshop, Melitopol: Publishing House of Melitopol City Printing House, 2017. - 277 p.

[8] Priss O., Yevlash V., Zhukova V., Kiurchev S., Verkholantseva V., Kalugina I., Kolesnichenko S., Salavelis A., Zolovska O., Bandurenko H. Investigation of the respiration rate during storage of fruit vegetables under the influence of abiotic factors. EUREKA: Life Sciences, (6), 2017, pp. 10-15.

[9] Yermakov S., Mudryk K., Hutsol T., Dziedzic K., Mykhailova L. The analysis of stochastic processes in unloadingthe energywillow cuttings from the hopper. Environment. Technology. Resources. Rezekne, Latvia. Proceedings of the 12th International Scientific and Practical Conference. Volume III. 2019. pp. 249-252

[10] Nazarova O., Osadchyy V. Shulzhenko S. (2019). Accuracy Improving of the Two-Speed Elevator Positioning by the Identification of Loading Degree. International Conference Modern Electrical and Energy Systems (MEES-19). Kremencuk Mykhailo Ostrogradskyi Universitu, Ukraine. 2019. pp. 50-53. DOI: 10.1109/MEES.2019.8896414. 